\title{
Clinical significance of Kelch-like protein 11 antibodies
}

Estibaliz Maudes, MSc, * Jon Landa, MSc, * Amaia Muñoz-Lopetegi, MD, Thaís Armangue, MD, PhD, Mercedes Alba, Albert Saiz, MD, PhD, Francesc Graus, MD, PhD, Josep Dalmau, MD, PhD, and

Lidia Sabater, PhD

Neurol Neuroimmunol Neuroinflamm 2020;7:e666. doi:10.1212/NXI.0000000000000666

\section{Abstract}

\section{Objective}

To report the clinical and oncologic associations of antibodies against Kelch-like protein 11 (KLHL11-ab), recently suggested as biomarkers of a paraneoplastic brainstem cerebellar syndrome associated with testicular seminoma, and to determine the value of immunohistochemistry as a screening technique.

\section{Methods}

Studies included 432 sera or CSF from 329 patients with paraneoplastic (157) or autoimmune neurologic syndromes (172); 63 with neurologic symptoms and benign teratomas; 28 with small-cell lung cancer, and 12 healthy subjects. KLHL11-abs were examined using a cell-based assay (CBA) with HEK293 cells transfected with a human KLHL11 clone. The CBA specificity was confirmed by immunoprecipitation. All positive samples were examined by immunohistochemistry on rat brain sections.

\section{Results}

KLHL11-abs were detected in 32 patients by CBA, and patients' antibodies immunoprecipitated KLHL11. Using rat brain immunohistochemistry, only 7 samples $(22 \%)$ were positive. Patients' median age was 28 years (range 9-76 years), and 16 (50\%) were women. Tumors were identified in 23/32 (72\%) patients, including 14 teratomas and 7 seminomas or mixed germ cell tumors. Thirteen (41\%) patients had cerebellar ataxia (7) or encephalitis with brainstem cerebellar symptoms (6), 7 (22\%) anti-NMDA receptor (NMDAR) encephalitis (5 with ovarian teratoma), 5 (16\%) opsoclonus-myoclonus, 3 (9\%) limbic encephalitis, and 4 (12\%) diverse neurologic symptoms ( 3 with benign teratomas). Concurrent autoantibodies occurred in 14 (44\%) patients (7 anti-NMDAR, $6 \mathrm{Ma} 2$, and $1 \mathrm{Hu}$ ).

\section{Conclusions}

KLHL11-abs associate with a spectrum of syndromes and tumors wider than those previously reported; $44 \%$ of patients have concurrent neuronal antibodies, some of them (anti-NMDAR) pathogenically relevant. Brain immunostaining is not useful for routine screening of KLHL11-abs.
Correspondence

Dr. Sabater

lisabate@clinic.cat 


\section{Glossary}

CBA = cell-based assay; Ma2-ab = Ma2 antibody; NMDAR = NMDA receptor; NMOSD = neuromyelitis optica spectrum disorder; PFA = paraformaldehyde; PNS = paraneoplastic neurologic syndrome; SCLC = small-cell lung cancer.

Identification of new biomarkers of paraneoplastic neurologic syndromes (PNSs) is important because they assist in the diagnosis of the neurologic disease and guide the tumor search. Patients with Ma2 antibodies (Ma2-abs) develop a combination of limbic, diencephalic, and upper brainstem encephalitis that in young men associate with testicular cancer. ${ }^{1}$ Recently, Mandel-Brehm et al. ${ }^{2}$ reported a new autoantibody against Kelch-like protein 11 (KLHL11-ab) in 13 patients with paraneoplastic brainstem cerebellar encephalitis and testicular seminoma without Ma2-abs. Here, we determined the frequency of KLHL11-abs in a larger series of patients with PNS or with nonparaneoplastic autoimmune encephalitis. In addition, we assessed the value of routine brain immunohistochemistry to detect these antibodies.

\section{Methods}

\section{Patients}

We retrospectively assessed the presence of KLHL11-abs in 432 serum or CSF samples of 329 patients with PNS (157) or autoimmune neurologic syndromes (172), 63 with diverse neurologic symptoms in the setting of a benign teratoma (ovary or testicular), 28 with small-cell lung cancer (SCLC) without neurologic symptoms, and 12 healthy subjects. Among the 157 patients with definite or possible PNS, ${ }^{3} 121$ had onconeural antibodies (61 Ma2, $40 \mathrm{Yo}$, and $20 \mathrm{Hu}$ antibodies), and 36 had cancer without onconeural antibodies ( 17 SCLC, 8 bladder cancer, 6 testicular seminomas, 1 germ cell tumor of the thymus, 2 neuroblastomas, and 2 suspected ovarian and testicular cancer). The remaining 172 patients had autoimmune disorders: 78 anti-NMDA receptor (NMDAR) encephalitis (47 with ovarian teratoma), $38 \mathrm{MS}$, 35 neuromyelitis optica spectrum disorder (NMOSD), 14 opsoclonus-myoclonus, and 7 other autoimmune-related neurologic conditions.

\section{Detection of KLHL11-abs by cell-based assay}

Transfection of Myc-DDK-tagged KLHL11 human complementary DNA (\#RC205228; Origene, Rockville, MD) in HEK293 cells was performed following standard procedures. Transfected cells were fixed with $4 \%$ paraformaldehyde (PFA) for 15 minutes, blocked with $10 \%$ goat serum with $0.1 \%$ Triton for 1 hour, and sequentially incubated with the patient's sample (serum 1:10.000, CSF 1:1,000) and a commercial KLHL11-ab (1:1,000, \#HPA054269; Sigma-Aldrich, St. Louis, $\mathrm{MO}$ ) for 2 hours, and the corresponding secondary antibodies (1:1,000, anti-human Alexa488 \#A-11013, antirabbit Alexa594 \#A-11005; Thermo-Fisher Scientific, Waltham, MA) for 1 hour. Slides were mounted with Prolong gold antifade reagent (Thermo-Fisher Scientific), and images were taken with a Zeiss LSM710 microscope (Carl-Zeiss, Jena, Germany). ${ }^{4}$

\section{Brain immunostaining with peroxidase and fluorescence techniques}

These studies were performed using reported techniques including biotin-avidin peroxidase on frozen sections of rat brain perfused with $2 \%$ PFA, followed by 4-hour postfixation with $2 \%$ PFA. ${ }^{5}$ Indirect immunofluorescence, to confirm the colocalization of human and commercial KLHL11-abs on the rat brain, was performed as in the cell-based assay (CBA) protocol described above.

\section{Immunoprecipitation and Western blot assay}

A lysate of HEK293 cells transfected with KLHL11 (total protein $500 \mu \mathrm{g})$ was incubated with serum samples (1:100) of patients with or without KLHL11-abs, for 1 hour at room temperature, precipitated with protein $\mathrm{A} / \mathrm{G}$ (Thermo-Fisher Scientific), separated in an acrylamide gel (\#NP03222; Thermo-Fisher Scientific), and transferred to nitrocellulose (\#1704158; Bio-Rad, Hercules, $\mathrm{CA})$. Strips were then incubated with the indicated commercial rabbit KLHL11-ab $(1: 1,000)$ overnight at $4^{\circ} \mathrm{C}$, followed by a secondary anti-rabbit horseradish peroxidase (\#NA934V; GE Healthcare, Chicago, IL) for 1 hour, and the reactivity developed with chemiluminescence. ${ }^{4}$

\section{Standard protocol approvals, registrations, and patient consents}

The study was approved by the internal review board of Hospital Clinic (\#HCB/2018/0192 protocol). Consent was obtained from all patients or proxies for the use serum and for research purposes.

\section{Data availability}

All data are reported within the article and available anonymized by request from qualified investigators.

\section{Results}

\section{KLHL11-ab detection}

KLHL11-abs were demonstrated in 32 patients by CBA (figure 1, A-F). CSF was available in 13 of 22 patients with KLHL11-abs in serum, and all CSF samples were also positive. To assure the specificity of the CBA, we selected KLHL11-ab-positive samples of 4 patients with different syndromes (cerebellar ataxia and seminoma, Ma2ab-associated brainstem diencephalic encephalitis, and germ cell testicular tumor; opsoclonus-myoclonus with ovarian teratoma; and anti-NMDAR encephalitis with ovarian teratoma) for immunoprecipitation using KLHL11-expressing 

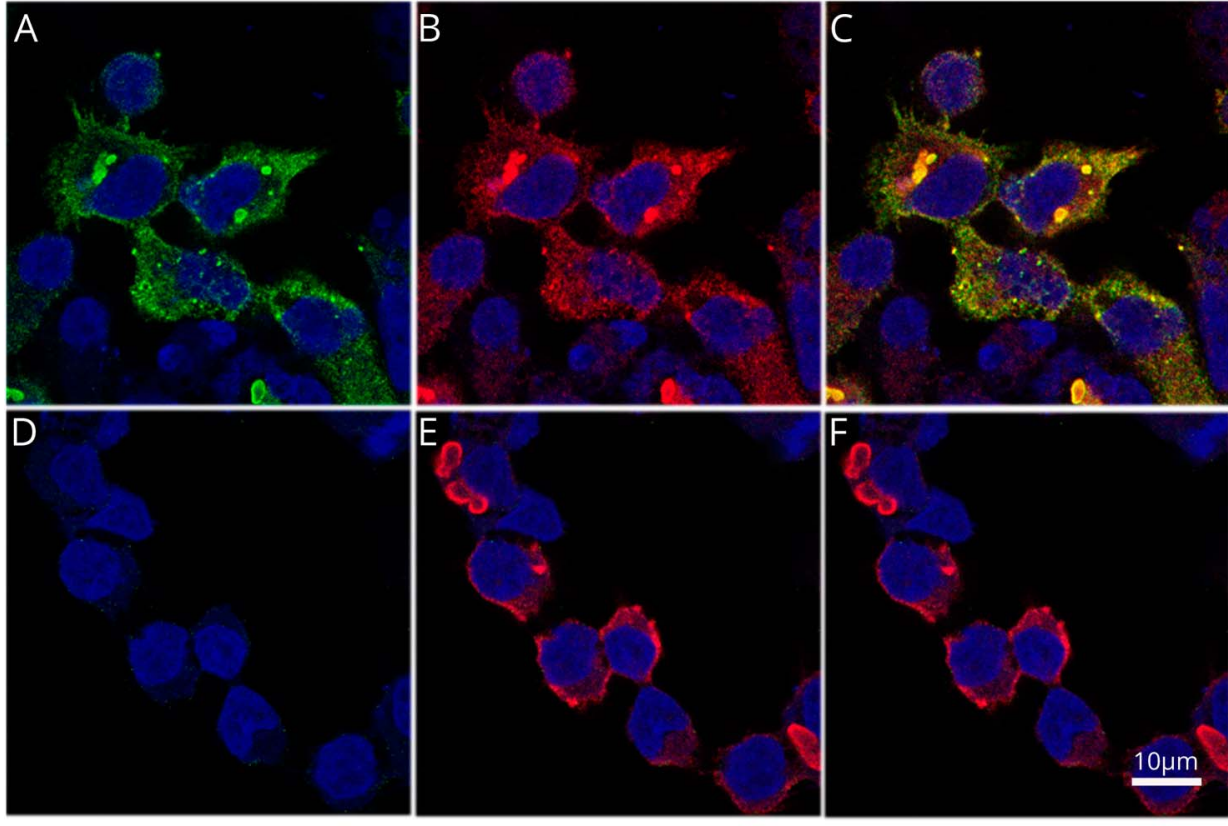

G
(A) Reactivity (green) of a representative patient's serum with HEK293 cells expressing KLHL11. No immunoreactivity is observed with a serum control (D). (B and E) Reactivity (red) of a commercial KLHL11-ab. (C and F) Merged reactivities of the indicated samples (patient and control samples) with the commercial KLHL11-ab, showing a perfect colocalization with patients' antibodies. Scale bar $=10 \mu \mathrm{m}$. (G) Western blot showing that the indicated patients' serum samples with KLHL11ab (lanes 2-5) immunoprecipitated KLHL11. Lane 1 shows the immunoprecipitation using the commercial antibody, and lanes 6-9 demonstrate the lack of KLHL11 immunoprecipitation with the indicated control samples. Lane 10 is the lack of immunoprecipitation of KLHL11 using untransfected HEK293 cells and serum of a patient with KLHL11-ab.
HEK293 cells. Samples of patients containing KLHL11-abs but none of the controls (Ma2-ab-associated brainstem diencephalic encephalitis; 2 anti-NMDAR encephalitis, anda normal human serum), immunoprecipitated KLHL11 (figure 1G).

All 32 KLHL11-ab-positive samples were also examined using rat brain immunohistochemistry. Samples of 7 (22\%) patients showed a robust reactivity with the cytoplasm of large neurons in the brainstem and deep cerebellar nuclei that colocalized with that produced by a commercial KLHL11-ab, confirming the specificity of patients' KLHL11-abs (figure 2).

\section{Clinical profile of the 32 patients with KLHL11-abs}

Patients' median age was 28.5 years (range 9-76 years), $16(50 \%)$ were women, and $23(72 \%)$ had a tumor (table). Benign teratomas were the most common associated tumors found in $14(44 \%)$ patients (10 in the ovary and 4 in the testis). Seven (22\%) patients had seminomas or mixed germ cell tumors (testicular 6 and thymus 1), 1 SCLC, and 1 ovarian cancer. Overall, 13 (41\%) patients had cerebellar ataxia ( 7 patients) or cerebellar brainstem symptoms in the context of extensive encephalitis $(6) ; 11$ of these 13 patients had benign teratomas or germ cell tumors, and 5 harbored concurrent autoantibodies (4 Ma2 and $1 \mathrm{Hu}$ ). Seven (22\%) patients had anti-NMDAR encephalitis, 5 of them with ovarian teratoma; 5 (16\%) had opsoclonus-myoclonus, and 3 (9\%) had limbic encephalitis, 2 of them with concomitant
Ma2-abs. Four additional patients (12\%) had heterogeneous neurologic symptoms, which in 3 associated with benign teratomas. Serum from patients with MS, NMOSD, SCLC without neurologic symptoms, and healthy controls were KLHL11-ab negative.

\section{Discussion}

The current findings show that the clinical and oncologic associations of KLHL11-abs are much wider than previously reported and that $44 \%$ of patients had concurrent neuronal antibodies, some of them (anti-NMDAR) pathogenically relevant.

As reported, ${ }^{2}$ we found a high frequency (72\%) of tumors in patients with KLHL11-abs, but the majority were benign teratomas of the ovary or testis. This association cannot be explained by the selection of patients with anti-NMDAR encephalitis, as $50 \%$ of patients with ovarian teratomas and KLHL11-ab had other syndromes. Seminomas and mixed germ cell testicular tumors were the second most common tumor type, but, unlike the initial study, ${ }^{2} 57 \%$ of these patients had Ma2-abs. The fact that we examined a larger number of patients with Ma2-abs (61 vs 8 ) could explain this discrepancy.

Based on this and previous findings, KLHL11-abs can be identified in 3 clinical settings (table): (1) CNS syndromes with 

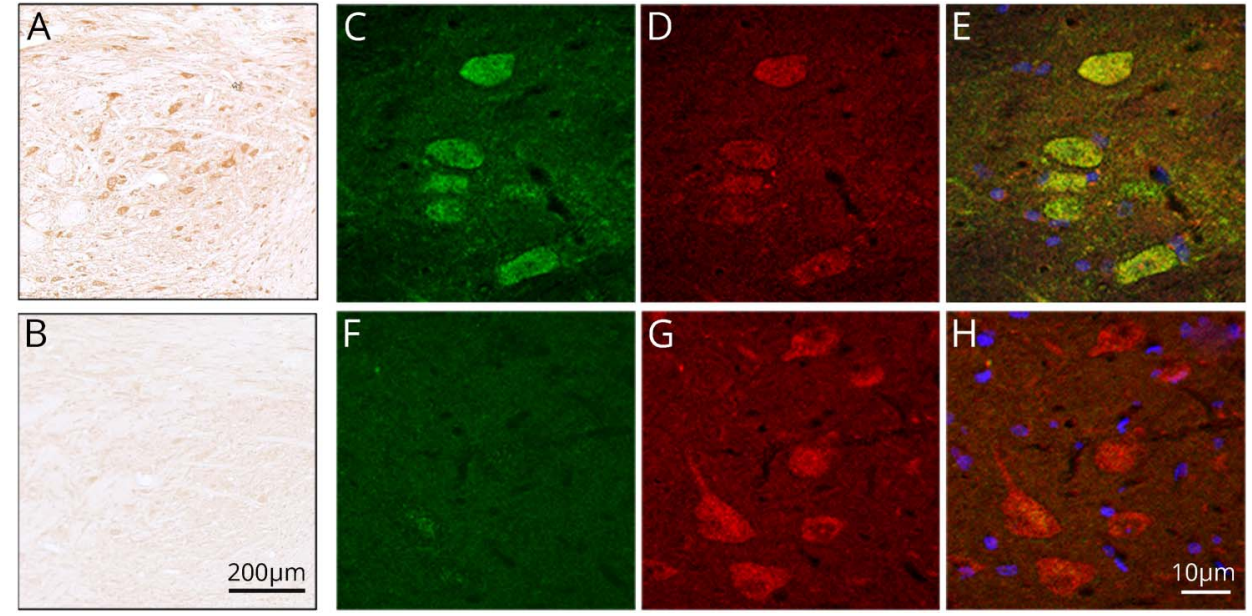

Immunohistochemistry on rat brain sections showing cytoplasmic staining of neurons of deep cerebellar nuclei incubated by a representative patient's serum with KLHL11-ab (A) and a negative control (B). Scale bar $=200 \mu \mathrm{m}$. Panel $C$ shows the reactivity (green) of a representative patient's serum with HEK293 cells expressing KLHL11. No immunoreactivity is observed with a serum control (F). Panels D and G show the reactivity (red) of a commercial KLHL11ab. Panels $\mathrm{E}$ and $\mathrm{H}$ show the merged reactivities of the indicated samples (patient's and control samples) with the commercial KLHL11-ab, showing a perfect colocalization with patient's antibodies (E). Scale bar $=10 \mu \mathrm{m}$.

a predominant, but not exclusive, brainstem cerebellar involvement. KLHL11-abs (with or without Ma2-abs) frequently occur with tumors (benign teratoma or a testicular tumor) and associate with limited or moderate response to treatment (although one of our patients with a mixed germ cell tumor of the thymus and cerebellar ataxia had a notable improvement after steroids $)^{6}$; (2) some patients with well-defined syndromes (anti-NMDAR encephalitis) have concurrent KLHL11-abs. In these cases, detection of KLHL11-abs does not change the clinical features or prognosis of classical anti-NMDAR encephalitis (e.g., 6 of 7 patients had substantial improvement [data not shown]); therefore, in this setting, detection of KLHL11-abs does not appear to have neurologic implications. The paradigm is similar to glial fibrillary acidic protein antibodies as accompaniments of anti-NMDAR encephalitis or $\mathrm{NMOSD}^{7}$; and (3) about 5\% (3 of 63) of the patients with neurologic syndromes that are not paraneoplastic or autoimmune may harbor KLHL11-abs associated with the presence of a teratoma.

Table Clinical profile of patients with KLHL11-abs

\begin{tabular}{|c|c|c|c|c|}
\hline Neurologic syndrome (N) & Age (median [range]) & $\operatorname{Sex}(F / M)$ & Tumors (N) & Other antibodies $(\mathrm{N})$ \\
\hline Anti-NMDAR encephalitis (7) & 19 [13-29] & $6 / 1$ & Ovarian teratoma (5) & Anti-NMDAR (7) \\
\hline \multirow[t]{4}{*}{ Cerebellar ataxia (7) } & $43[15-57]$ & $2 / 5$ & Seminoma (2) & \\
\hline & & & Ovarian teratoma (2) & \\
\hline & & & Testicular teratoma (2) & \\
\hline & & & Germ cell thymic tumor $(1)^{a}$ & \\
\hline \multirow[t]{3}{*}{ Brainstem diencephalic encephalitis (6) } & 37 [22-65] & $0 / 6$ & Seminoma (2) & Anti-Ma2 (4) \\
\hline & & & Germ cell testicular tumor (2) & Anti-Hu (1) \\
\hline & & & $\operatorname{SCLC}(1)$ & \\
\hline \multirow[t]{2}{*}{ Opsoclonus-myoclonus (5) } & $37[31-48]$ & $5 / 0$ & Ovarian teratoma (1) & \\
\hline & & & Ovarian carcinoma (1) & \\
\hline Limbic encephalitis (3) & $48[12-76]$ & $1 / 2$ & Testicular teratoma (1) & Anti-Ma2 (2) \\
\hline Chronic psychosis (2) & 26,19 & $F, M$ & Teratoma (2; ovarian, testicular) & \\
\hline Subacute encephalopathyb (1) & 36 & $\mathrm{~F}$ & Ovarian teratoma (1) & \\
\hline Extralimbic encephalitis ${ }^{c}(1)$ & 9 & $M$ & & \\
\hline
\end{tabular}

Abbreviations: NMDAR = NMDA receptor; $\mathrm{SCLC}=$ small-cell lung cancer.

a Previously reported. ${ }^{6}$

b Subacute encephalopathy the setting of alcohol abuse.

c Cause unknown. 
KLHL11 is a protein member of the E3 ubiquitin ligase complex, and the intracellular location indicates that the antibodies cannot interfere with its function in vivo. Therefore, any immune mechanism related to KLHL11-abs and tumor or neurologic autoimmunity is likely $\mathrm{T}$ cell mediated.

A task for the future is to assess whether KLHL11 is frequently expressed by nonparaneoplastic tumors, particularly seminomas and mixed germinomas, and whether patients with these tumors without neurologic symptoms harbor these antibodies.

\section{Acknowledgment}

The authors thank Prof. Alexander Lossos, Department of Oncology and Neurology of the Hadassah-Hebrew University Medical Center, Jerusalem, Israel, and Dr. Joan Montaner, Service of Neurology, Hospital Vall d'Hebrón, Barcelona, Spain, for providing complete clinical data of patients.

\section{Study funding}

This study was supported in part by Instituto Carlos III/ FEDER, Madrid (FIS 18/00067 [L. Sabater], FIS 17/00234, J. Dalmau; PIE 16/00014, J. Dalmau; CIBERER \# CB15/ 00010, J. Dalmau); PERIS SLT006/17/00362, T. Armangue); Mutua Madrileña Foundation Award (AP162572016, T. Armangue); La Caixa Foundation Health Research, J. Dalmau; and Fundació CELLEX, J. Dalmau.

\section{Disclosure}

E. Maudes, J. Landa, and A. Muñoz report no disclosures. T. Armangue received speaker honoraria from Novartis (not related to this study). M. Alba reports no disclosures. A. Saiz received compensation for consulting services and speaker honoraria from Bayer-Schering, Merck-Serono, Biogen Idec, Genzyme-Sanofi, TEVA, Novartis, and Roche. F. Graus receives royalties from Euroimmun for the use of IgLON5 as an autoantibody test and honoraria for Assistant Editor of MedLink Neurology. J. Dalmau receives royalties from Athena Diagnostics for the use of $\mathrm{Ma} 2$ as an autoantibody test and from Euroimmun for the use of NMDA as an autoantibody test. J. Dalmau received a licensing fee from Euroimmun for the use of GABAB receptor, GABAA receptor, DPPX, and IgLON5 as autoantibody tests. L. Sabater reports no disclosures. Go to Neurology.org/NN for full disclosures.

\section{Publication history}

Received by Neurology: Neuroimmunology \& Neuroinflammation November 7, 2019. Accepted in final form December 17, 2019.

Appendix Authors

\begin{tabular}{|c|c|c|c|}
\hline Name & Location & Role & Contribution \\
\hline $\begin{array}{l}\text { Estibaliz } \\
\text { Maudes, } \\
\text { MSc }\end{array}$ & $\begin{array}{l}\text { IDIBAPS, Barcelona, } \\
\text { Spain }\end{array}$ & Author & $\begin{array}{l}\text { Analyzed the data; } \\
\text { immunohistochemical } \\
\text { and } \\
\text { immunoprecipitation } \\
\text { studies; and revised } \\
\text { the manuscript for } \\
\text { intellectual content }\end{array}$ \\
\hline
\end{tabular}

Appendix (continued)

\begin{tabular}{|c|c|c|c|}
\hline Name & Location & Role & Contribution \\
\hline $\begin{array}{l}\text { Jon Landa, } \\
\text { MSc }\end{array}$ & $\begin{array}{l}\text { IDIBAPS, Barcelona, } \\
\text { Spain }\end{array}$ & Author & $\begin{array}{l}\text { Analyzed the data; } \\
\text { immunohistochemical } \\
\text { and } \\
\text { immunoprecipitation } \\
\text { studies; and revised } \\
\text { the manuscript for } \\
\text { intellectual content }\end{array}$ \\
\hline $\begin{array}{l}\text { Amaia } \\
\text { Muñoz- } \\
\text { Lopetegi, } \\
\text { MD }\end{array}$ & $\begin{array}{l}\text { Hospital Clínic and } \\
\text { IDIBAPS, Barcelona, } \\
\text { Spain }\end{array}$ & Author & $\begin{array}{l}\text { Analysis and } \\
\text { interpretation of the } \\
\text { data and revised the } \\
\text { manuscript for } \\
\text { intellectual content }\end{array}$ \\
\hline $\begin{array}{l}\text { Thaís } \\
\text { Armangue, } \\
\text { MD, PhD }\end{array}$ & $\begin{array}{l}\text { Hospital Clínic and } \\
\text { IDIBAPS, Hospital } \\
\text { Sant Joan de Deu, } \\
\text { Barcelona, Spain }\end{array}$ & Author & $\begin{array}{l}\text { Acquisition of clinical } \\
\text { data and revised the } \\
\text { manuscript for } \\
\text { intellectual content }\end{array}$ \\
\hline $\begin{array}{l}\text { Mercedes } \\
\text { Alba }\end{array}$ & $\begin{array}{l}\text { IDIBAPS, Barcelona, } \\
\text { Spain }\end{array}$ & Author & $\begin{array}{l}\text { Immunohistochemical } \\
\text { studies and revised the } \\
\text { manuscript }\end{array}$ \\
\hline $\begin{array}{l}\text { Albert Saiz, } \\
\text { MD, PhD }\end{array}$ & $\begin{array}{l}\text { Hospital Clínic and } \\
\text { IDIBAPS, Barcelona, } \\
\text { Spain }\end{array}$ & Author & $\begin{array}{l}\text { Acquisition of clinical } \\
\text { data; analysis and } \\
\text { interpretation of the } \\
\text { data; and revised the } \\
\text { manuscript for } \\
\text { intellectual content }\end{array}$ \\
\hline $\begin{array}{l}\text { Francesc } \\
\text { Graus, MD, } \\
\text { PhD }\end{array}$ & $\begin{array}{l}\text { IDIBAPS, Barcelona, } \\
\text { Spain }\end{array}$ & Author & $\begin{array}{l}\text { Acquisition of clinical } \\
\text { data; analysis and } \\
\text { interpretation of the } \\
\text { data; and revised the } \\
\text { manuscript for } \\
\text { intellectual content }\end{array}$ \\
\hline $\begin{array}{l}\text { Josep } \\
\text { Dalmau, } \\
\text { MD, PhD }\end{array}$ & $\begin{array}{l}\text { Hospital Clínic and } \\
\text { IDIBAPS, Barcelona, } \\
\text { Spain }\end{array}$ & Author & $\begin{array}{l}\text { Acquisition of clinical } \\
\text { data; analysis and } \\
\text { interpretation of the } \\
\text { data; and revised the } \\
\text { manuscript for } \\
\text { intellectual content. } \\
\text { Funding }\end{array}$ \\
\hline $\begin{array}{l}\text { Lidia } \\
\text { Sabater, } \\
\text { PhD }\end{array}$ & $\begin{array}{l}\text { IDIBAPS, Barcelona, } \\
\text { Spain }\end{array}$ & Author & $\begin{array}{l}\text { Drafted the first } \\
\text { version of the } \\
\text { manuscript; analysis } \\
\text { and interpretation } \\
\text { of the data; and } \\
\text { revised the } \\
\text { manuscript for } \\
\text { intellectual content }\end{array}$ \\
\hline
\end{tabular}

\section{References}

1. Dalmau J, Graus F, Villarejo A, et al. Clinical analysis of anti-Ma2-associated encephalitis. Brain 2004;127:1831-1844.

2. Mandel-Brehm C, Dubey D, Kryzer TJ, et al. Kelch-like protein 11 antibodies in seminoma-associated paraneoplastic encephalitis. N Engl J Med 2019;381: 47-54

3. Graus F, Delattre JY, Antoine JC, et al. Recommended diagnostic criteria for paraneoplastic neurological syndromes. J Neurol Neurosurg Psychiatry 2004;75: 1135-1140.

4. Sabater L, Gaig C, Gelpi E, et al. A novel non-rapid-eye movement and rapid-eyemovement parasomnia with sleep breathing disorder associated with antibodies to IgLON5: a case series, characterisation of the antigen, and post-mortem study. Lancet Neurol 2014;13:575-586.

5. Graus F, Dalmau J, Valldeoriola F, et al. Immunological characterization of a neuronal antibody (anti-Tr) associated with paraneoplastic cerebellar degeneration and Hodgkin's disease. J Neuroimmunol 1997;74:55-61.

6. Sola-Valls N, Gaba L, Munoz E, et al. Paraneoplastic cerebellar degeneration associated with thymic germinoma. J Neurol Sci 2012;320:153-155.

7. Flanagan EP, Hinson SR, Lennon VA, et al. Glial fibrillary acidic protein immunoglobulin $\mathrm{G}$ as biomarker of autoimmune astrocytopathy: analysis of 102 patients. Ann Neurol 2017;81:298-309. 


\section{Neurology $^{\odot}$ \\ Neuroimmunology \& Neuroinflammation}

Clinical significance of Kelch-like protein 11 antibodies

Estibaliz Maudes, Jon Landa, Amaia Muñoz-Lopetegi, et al.

Neurol Neuroimmunol Neuroinflamm 2020;7;

DOI 10.1212/NXI.0000000000000666

This information is current as of January 17, 2020

\section{Updated Information \& Services}

References

Citations

Subspecialty Collections

Permissions \& Licensing

Reprints including high resolution figures, can be found at: http://nn.neurology.org/content/7/3/e666.full.html

This article cites 7 articles, 1 of which you can access for free at: http://nn.neurology.org/content/7/3/e666.full.html\#\#ref-list-1

This article has been cited by 3 HighWire-hosted articles: http://nn.neurology.org/content/7/3/e666.full.html\#\#otherarticles

This article, along with others on similar topics, appears in the following collection(s):

All Clinical Neurology

http://nn.neurology.org//cgi/collection/all_clinical_neurology Autoimmune diseases

http://nn.neurology.org//cgi/collection/autoimmune_diseases Paraneoplastic syndrome

http://nn.neurology.org//cgi/collection/paraneoplastic_syndrome

Information about reproducing this article in parts (figures,tables) or in its entirety can be found online at:

http://nn.neurology.org/misc/about.xhtml\#permissions

Information about ordering reprints can be found online: http://nn.neurology.org/misc/addir.xhtml\#reprintsus

Neurol Neuroimmunol Neuroinflamm is an official journal of the American Academy of Neurology.

Published since April 2014, it is an open-access, online-only, continuous publication journal. Copyright

Copyright (C) 2020 The Author(s). Published by Wolters Kluwer Health, Inc. on behalf of the American

Academy of Neurology.. All rights reserved. Online ISSN: 2332-7812.

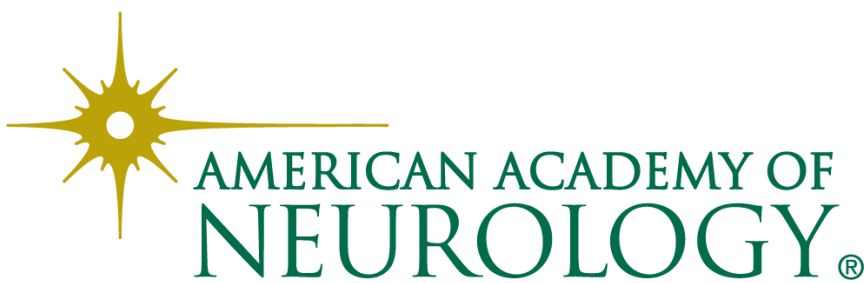

